DOI: 10.19085/journal.sijbpg031001

\title{
Macroeconomic Imbalances and the Economic Convergence of the EU candidate countries
}

\author{
Assoc. Prof. Dr. Daniela Bobeva \& Dr. DimitarZlatinov
}

(c) Scholedge International Journal of Business Policy \& Governance (ISSN 2394-3351), Vol.03, Issue 10 (2016) pg135-154. Published by: Scholedge R\&D Center [http://www.thescholedge.org/journals/] [Email: editorial@thescholedge.org]

\begin{abstract}
The paper assesses the relevance of the EU Macroeconomic Imbalances Procedure scoreboard for the EU candidate countries. The calculation of the 14 indicators for a nine years period proves the recent economic crisis helped resolve some of the imbalances in the EU candidate countries but on the back of the slowing down the economic growth and convergence. The paper argues that MIP scoreboard fails to capture the specifics of economic developments of the caching up economies and cannot be used as a tool for assessing their readiness to join the EU.
\end{abstract}

Key words: Economic growth, Macroeconomic Imbalances, Macroeconomic Imbalances Procedure scoreboard, convergence, EU candidate countries, remittances.

JEL classification number: E61, E66, H12

In November 2015, the European Commission (EC) initiated the fifth annual round of the Macroeconomic Imbalance Procedure (MIP). In its substance the MIP is a surveillance mechanism which aims to detect and address economic imbalances that may significantly affect EU economic development and put at risk the proper functioning of EU Single market. Although the issue of macroeconomic imbalances is not sufficiently studied in economic theory, the global financial and economic crisis of 2007-2008 puts macroeconomic imbalances at the center of political debates. At European level the idea for the macroeconomic imbalances scoreboard has been developed and it forms the basis of the MIP. The MIP scoreboard could be defined as a politically motivated instrument that mechanically collects various economic indicators, whose isolated consideration of overall economic dynamics could lead to misleading conclusions and erroneous recommendations. Based on results of such scoreboard of 14 indicators that are subject to an economic reading by the EC, the EC may propose the countries for which imbalances are considered excessive to be subject to a specific monitoring or even sanctions for the euro area Member States in case of repeated lack of compliance with scoreboard thresholds and EC judgment. Therefore, the MIP scoreboard is an influential policy tool and its central role in the EU economic governance framework deserves special attention not only for assessing the EU Member States economic stability, but also for the EU candidate countries whose economic performance is already undergoing assessment in the spirit of MIP principles.

In this paper we present the results from calculation of 6out of 14MIP scoreboard indicators for 9 years for the EU candidate countries, namely Albania, FYR of Macedonia, Montenegro, Serbia and 
Turkey putting the emphasis on the rationale of applying the MIP scoreboard for assessing their economic convergence to the EU. The period under review covers 2008-2015 which aims at clarifying the impact of the crisis on EU candidate countries convergence to the EU and allows us to analyse the macroeconomic imbalances in dynamics taking into account the constraints posed by insufficient availability of statistical data to calculate all included in the MIP scoreboard indicators. However, only the MIP scoreboard indicators are not enough to properly assess the economic development in the countries under review. That is why in this paper we use additional indicators such as FDI inflows, migrant remittances, investment gap, budget deficit, etc. As a significant additional indicator we outline the FDI inflows which help us analyse the effect of the crisis on the EU candidate countries development and their economic growth model.

The main issues discussed in the paper are: first, the relevance of using the MIP scoreboard as a tool for assessing the vulnerabilities and imbalances of the EU candidate countries and, second, what it shows about their macroeconomic readiness to join the EU. The results of the calculation of the score board indicators for the EU candidate countries show that such tool cannot be useful to assess their economic stability which is motivated not only by insufficient statistical data but with the wrong signals for necessary economic policy that scoreboard can give. We also argue that the EU alert mechanism based on the MIP scoreboard does not take into account the specificities of the catching-up economies and its implications may be misleading for both the markets and the policy makers and if strictly applied it may even negatively affect the pace of their economic convergence. Reduced external imbalances in the EU candidate countries in the post-crisis period largely reflect limited FDI inflows to their economies and the change in their economic development model than targeted efforts by the macroeconomic elite. This fact only illustrates that the MIP scoreboard is much more useful for one-side reporting of certain economic processes, but not the reason for conducting economic policy and making recommendations at political level. Last but not least, such conclusions from the application of the tools of MIP help understand the mechanism of economic convergence not only for EU candidate countries but even for EU Member States themselves.

\section{The MIP scoreboard dilemma}

The scoreboard for the surveillance of macroeconomic imbalances under the MIP is part of the MIP's alert mechanism. It consists of a scoreboard with 14 headline indicators covering external and internal macroeconomic imbalances. The scoreboard includes both stock and flow indicators with indicative upper and lower alert thresholds which are differentiated for euro and non-euro area Member States. The reading of headline indicators is complemented by 25 auxiliary indicators such as economic growth, nominal and real convergence inside and outside the euro area, productivity developments, foreign and domestic investment, as well as sectoral developments, which affect GDP and current account performance. The initial screening of macroeconomic imbalances is mandated to the Alert Mechanism Report which identifies the Member States whose developments warrant further in-depth analysis to determine whether imbalances exist. The nature of the imbalances and their gravity are subject to the follow-up indepth analysis country by country. 
Figure 1: The MIP Scoreboard Indicators

\begin{tabular}{|c|c|}
\hline Indicator & Threshold \\
\hline $\begin{array}{l}\text { Three-year backward moving average of the } \\
\text { current account balance as percent of GDP }\end{array}$ & $+6 \%$ of GDP and $-4 \%$ of GDP \\
\hline $\begin{array}{l}\text { Net international investment position as } \\
\text { percent of GDP }\end{array}$ & $-35 \%$ of GDP \\
\hline $\begin{array}{l}\text { Five-year percentage change of export market } \\
\text { shares measured in values }\end{array}$ & $-6 \%$ \\
\hline $\begin{array}{l}\text { Three-year percentage change in nominal unit } \\
\text { labour cost }\end{array}$ & $\begin{array}{l}+9 \% \text { for euro area countries and }+12 \% \text { for non- } \\
\text { euro area countries }\end{array}$ \\
\hline $\begin{array}{l}\text { Three-year percentage change of the real } \\
\text { effective exchange rates based on } \mathrm{HICP} / \mathrm{CPI} \\
\text { deflators, relative to } 41 \text { other industrial } \\
\text { countries }\end{array}$ & $\begin{array}{l}-\mid+5 \% \text { for euro area countries and }-\mid+11 \% \text { for non- } \\
\text { euro area countries }\end{array}$ \\
\hline $\begin{array}{l}\text { Private sector debt (consolidated) in percent } \\
\text { of GDP }\end{array}$ & $133 \%$ of GDP \\
\hline Private sector credit flow in percent of GDP & $14 \%$ of GDP \\
\hline $\begin{array}{l}\text { Year-on-year changes in house prices relative } \\
\text { to a Eurostat consumption deflator }\end{array}$ & $6 \%$ \\
\hline $\begin{array}{l}\text { General government sector debt in percent of } \\
\text { GDP }\end{array}$ & $60 \%$ of GDP \\
\hline $\begin{array}{l}\text { Three-year backward moving average of } \\
\text { unemployment rate }\end{array}$ & $10 \%$ \\
\hline $\begin{array}{l}\text { Year-on-year changes in total financial sector } \\
\text { liabilities }\end{array}$ & $16.5 \%$ \\
\hline $\begin{array}{l}\text { Three-year change in percentage points of the } \\
\text { activity rate (in p.p.) }\end{array}$ & $-0.2 \%$ \\
\hline $\begin{array}{l}\text { Three-year change in percentage points of the } \\
\text { long-term unemployment rate (in p.p.) }\end{array}$ & $-0.5 \%$ \\
\hline $\begin{array}{l}\text { Three-year change in percentage points of the } \\
\text { youth unemployment rate (in p.p.) }\end{array}$ & $+2 \%$ \\
\hline
\end{tabular}

Not surprisingly for such a policy tool that encompasses so many functions in the EU economic governance framework its main principles have faced criticism. The ECB have emphasized that the judgment element of the scoreboard, even if necessitated by the complexity of the economic imbalances and the difficulty to assess them only on the grounds of a matrix of indicators, creates uncertainty and room for broad interpretation. The scoreboard's transparency is valued by the $E C B$ as a strong advantage. If the scoreboard does not detect the risks correctly, the signals it sends to the markets and society may be harmful.

The application of the scoreboard and the related MIP feed positively into the formulation of policy recommendations. The recommendations under the preventive arm of the MIP form part of the package of Country-specific recommendations put forward by the EC for adoption by the Council under the European Semester cycle. The recommendations are endorsed at the highest 
political level and their implementation is monitored closely by the Commission services. It forms peer pressure from other EU Member States and is a strong incentive for governments to pursue structural reforms and to tackle unsustainable economic developments. Meanwhile, the economic judgment on the economic process based only on a set of indicators may be misleading and even harmful with long-lasting negative effects.

As regards the structure of the scoreboard, the inclusion of the indicator that summarises the financial sector performance is often put into question since it may ignore the complexity of this sector. Moreover, the selected indicator for year-on-year changes in total financial sector liabilities does not take into account the different levels of development of financial sectors in the EU Member States and may "penalise" catching-up financial markets like those of the new members of the EU, in which financial intermediation is still catching up and needs more dynamics. Adding employment indicators in 2015 in the MIP scoreboard was strongly supported by the European Parliament (EP). The EP welcomed the EC's use of the new employment and social scoreboard for Country-specific Recommendations and calls for the inclusion of additional social and labour market indicators in the scoreboard which should have a real influence on the whole European Semester process (EP, 2014). The European Council criticized these proposals. As a result, it was decided that the expansion of the social dimensions set of scoreboard indicators will not lead to legal implications and flashes of the new employment indicators will not trigger further steps in the MIP (EC, 2015). Such debates and compromise clearly show that the MIP scoreboard is first of all a political concept and not an entire economic philosophy for assessing economic stability.

As a part of the communication role of the scoreboard, the EC announces a ranking of sorts for the countries according to the level of risks for their economies. This public message itself may fuel the negative market perceptions about those countries, warning investors about the risks in those contexts, thus further deteriorating their economic situation. Public communication on the MIP may also be a tool for putting pressure on national authorities and navigating their policy responses, which is beyond the mandate of the EC.

Another vague issue is the criteria according to which the Member States that incur imbalances are selected for the in-depth analysis. Still, it remains unclear which of the scoreboard indicators have the highest weight when the EC makes assessment with regard to whether a Member State experiences serious imbalances. Those uncertainties of the application of the scoreboard need further attention having in mind the importance of the scoreboard in shaping market perceptions and the EU economic governance framework. Last but not least, so far no EU Member States are placed under an Excessive Imbalance Procedure although severe imbalances have been already identified in many countries over the last5 years. This fact begs the question of how strong the imbalances should be in order to activate the procedure and cast a shadow over the transparency of applying the MIP criteria.

\section{Assessing imbalances in EU candidate countries}

The first indication that the MIP scoreboard can be used as a broader instrument to detect imbalances was the 2012 Convergence Report of the European Central Bank, where in Chapter 3 "the scoreboard indicators (including in relation to the alert thresholds) are presented for all 
countries covered in this Report, thereby ensuring the provision of all available information relevant to the detection of macroeconomic imbalances that may be hampering the achievement of a high degree of sustainable convergence as stipulated under Article 140(1) of the Treaty. Notably, the EU Member States with derogation that are subject to an Excessive Imbalance Procedure can hardly be considered as having achieved a high degree of sustainable convergence as stipulated by Article 140(1) of the Treaty" (ECB, 2012). In the 2014 Convergence Report the same reference was made. Obviously, the ECB has already used the scoreboard as a criterion for the sustainability of convergence and macroeconomic performance of EU Member States.

In the Commission's Reports on EU candidate countries' progress with regard to joining the EU the EC has already used MIP concepts when assessing the economic performance of future EU Member States, too. The EC evaluates their progress on the basis of the external and internal imbalances they experience and in the statistical annexes it tries to include MIP indicators as well. Moreover, since 2013 the FYR of Macedonia has presented voluntarily a comment on the indicators for the Macedonian economy in accordance with the MIP in its Pre-accession Economic Programme.

Since the ECB and EC considers the scoreboard an important assessment instrument for convergence and some of the $\mathrm{EU}$ candidate countries have already presented it in their economic programmes, it is beneficial to calculate the indicators of the scoreboard and to test the results for those countries. The main question here is: is economic convergence compatible with sustainable development of macroeconomic indicators and whether it is even possible if an economy is not experiencing any internal and external imbalances?

The first issue with the application of the scoreboard with a view to EU candidate countries is the problem with the statistical input. There are fundamental limitations that make this exercise incomplete and therefore not well grounded. The Eurostat provides statistical data only for some of those countries and in terms of some of the indicators. There are significant differences in the data sources and definitions in the EU candidate countries and, subsequently, there are doubts about the comparability of the data used. In addition, the use of different sources may yield less comparable results across countries, as well as create controversy. That is why we use the IMF statistics since it provides for good quality and internationally comparable data. However, the data limitation does allow for calculating the scoreboard indicators in full. Therefore, all results from the calculations have to be interpreted with caution, especially if the scoreboard is used as a tool for public communication. Nevertheless, there are reliable data available for the calculation of 6 out of 14 indicators, namely:

- three-year backward moving average of the current account balance as percent of GDP;

- net international investment position as percent of GDP;

- five-years percentage change of export market shares measured in values;

- general government sector debt in percent of GDP;

- three-year backward moving average of unemployment rate;

- three-year change in percentage points of the activity rate. 


\section{Assessing external imbalances in the EU candidate countries}

We assess the sustainability of external position of the EU candidate countries on the basis of their current account balance, net international investment position and export market shares. Unlike other indicators in the MIP scoreboard, the current account balance is widely analysed indicator in the economic literature and it is also commonly used in economic research. The net international investment position records the net financial position (assets minus liabilities) of the domestic sectors of the economy vis-a-vis the rest of the world. The five-years percentage change of export market shares aims at capturing structural losses in competitiveness.

\section{Current account deficit/surplus}

The scoreboard indicator focused on current account imbalances shows that all EU candidate countries except for FYR of Macedonia are below the lower threshold of the current account deficit for some years now. The countries never experience balances and current account surpluses.A positive tendency for all economies is that current account deficits continue declining in the most recent period.

Figure 2: Three year backward moving average of current account balance as a percentage of GDP, period for calculation 2006-2015

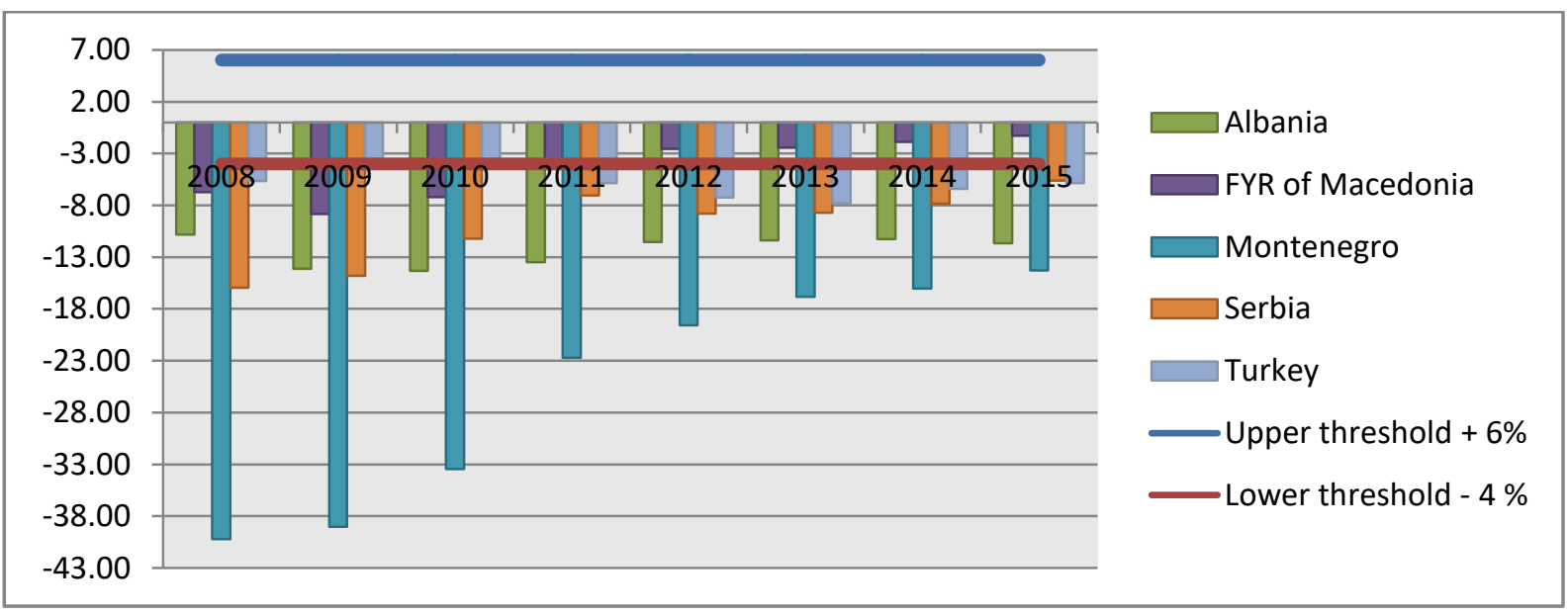

Source: IMF

Nevertheless, growing current account deficits are considered harmful to the economy as they may suffer unsustainable financing, losses of competitiveness and confidence by foreign investors, and decline in living standards. Along these lines, the candidate countries may be grouped as highly vulnerable ones and not sufficiently converged to their EU peers. However, it should be clearly emphasized that countries in the catching-up phase often run current account deficits as a result of investing in productive activities in response to changes in underlying structural characteristics and attracting foreign capital. Hence, such results are not surprising, taking into account the common economic development pattern in the catching-up Western Balkan countries and the specificities of Turkish economy. The growth model of the countries from the Western Balkans and the catching-up economies is characterized by a strong FDI-driven demand and analyzing them without taking into consideration the FDI inflows in these economies is not justified. Strong capital inflows in the EU candidate countries are a result of the openness of 
those economies as well as of their attractiveness related to the low production costs, non-rigid labour markets, lower level of taxation and the unsaturated markets. Especially for the Western Balkans countries in the early post-socialist period, FDI was the main instrument for economic reforms and also for accelerating economic growth, owing to the lack of accumulated national capital, poor market economy experience and the lacking entrepreneurial skills.

The current account deficit in Albania is structurally high for the entire period between 2006 and 2015. The three-year backward moving average of current account balance is above $-10 \%$ of GDP since 2008 combined with sluggish economic growth. The Albanian economic growth slowed in 2009 to $3.35 \%$ compared to $7.54 \%$ in 2008 and in 2015 the real GDP growth amounted to $2.64 \%$. Recovering domestic demand results in higher imports and attracting of foreign investments which drives the current account deficit.

Figure 3: Economic growth driven current account deficit in Albania

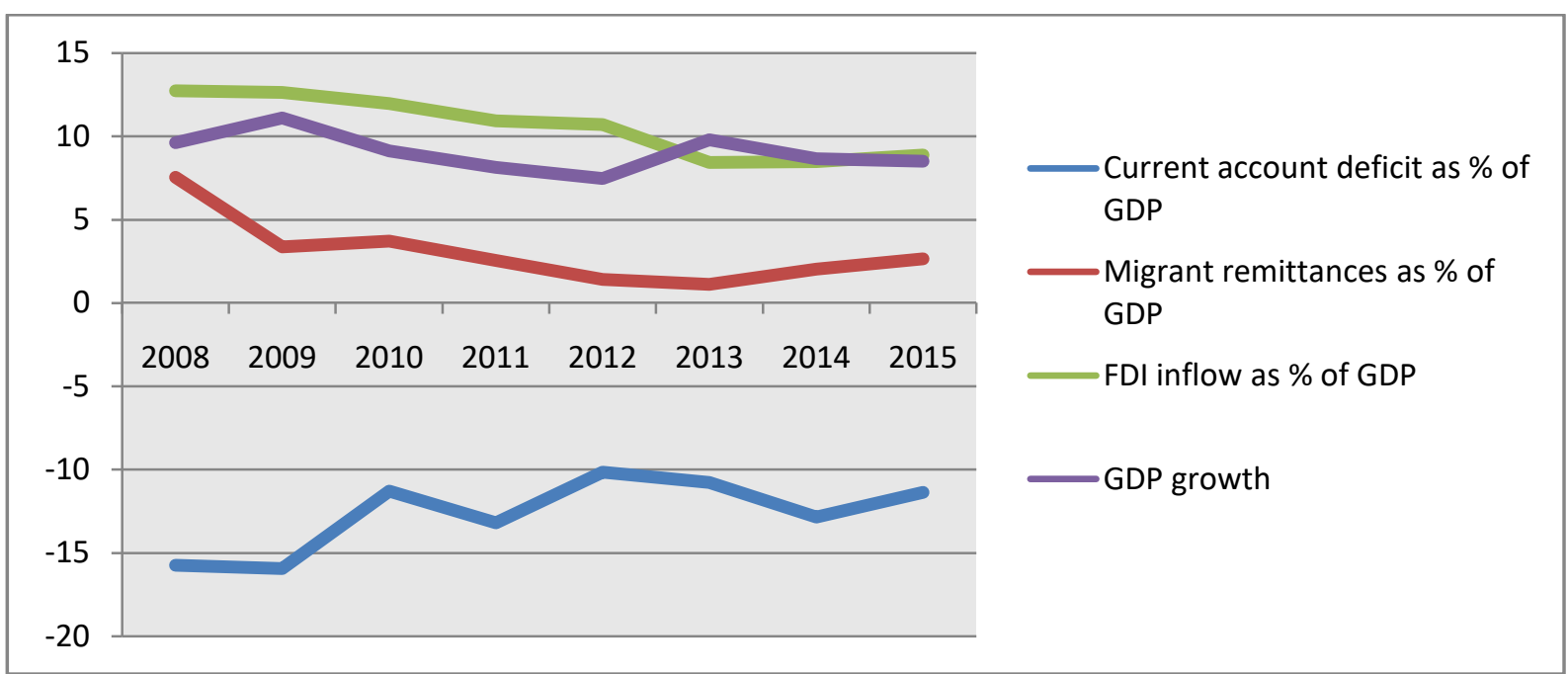

Source: IMF

The current account deficits in Albania also reflect the decline in migrant remittances which in the period under review are below the level reached before 2008. The financing of strong current account deficits in Albania relied mainly on non-debt creating flows. The FDI inflows exceed approximately four times the FDI outflows from the country in 2008-2009 and this tendency remains strong even beyond 2010. In 2013 the FDI inflow in Albania is bigger than the FDI inflow registered in the country before the crisis. Therefore, the Albanian current account deficit in the years after the global crisis is mainly affected by positive GDP growth and it is successfully financed by foreign capitals.

The external position of FYR of Macedonia presents a different experience when compared to that of Albania. The current account deficits in the country began to narrow since 2009 while the real GDP growth accelerated. The FDI inflows to the Macedonian economy shrank after the global crises and, compared to 2008, they decreased to one third in 2015. In such a macro-economic environment the correction of current account deficits in FYR of Macedonia is spurred largely by exports made by foreign investors in some sectors of the economy and cyclical factors as global decrease of the raw prices and the world economic crisis. Migrant remittances remained stable after 2008 and even growing in the post-crisis period which positively affected the current 
account balance but when used for consumption, migrant remittances may negatively affect the trade balance. In their substance, the factors behind low current account deficit in FYR of Macedonia also reflect the catching-up growth model but in a different way compared to Albania. Migrant remittances and foreign investors dominated export sectors contribute to a more balanced foreign trade structure of the economy which is not necessarily attributed to external competitiveness gains.

Figure 4: Migrant remittances driven reduction of the current account deficit in FYR of Macedonia

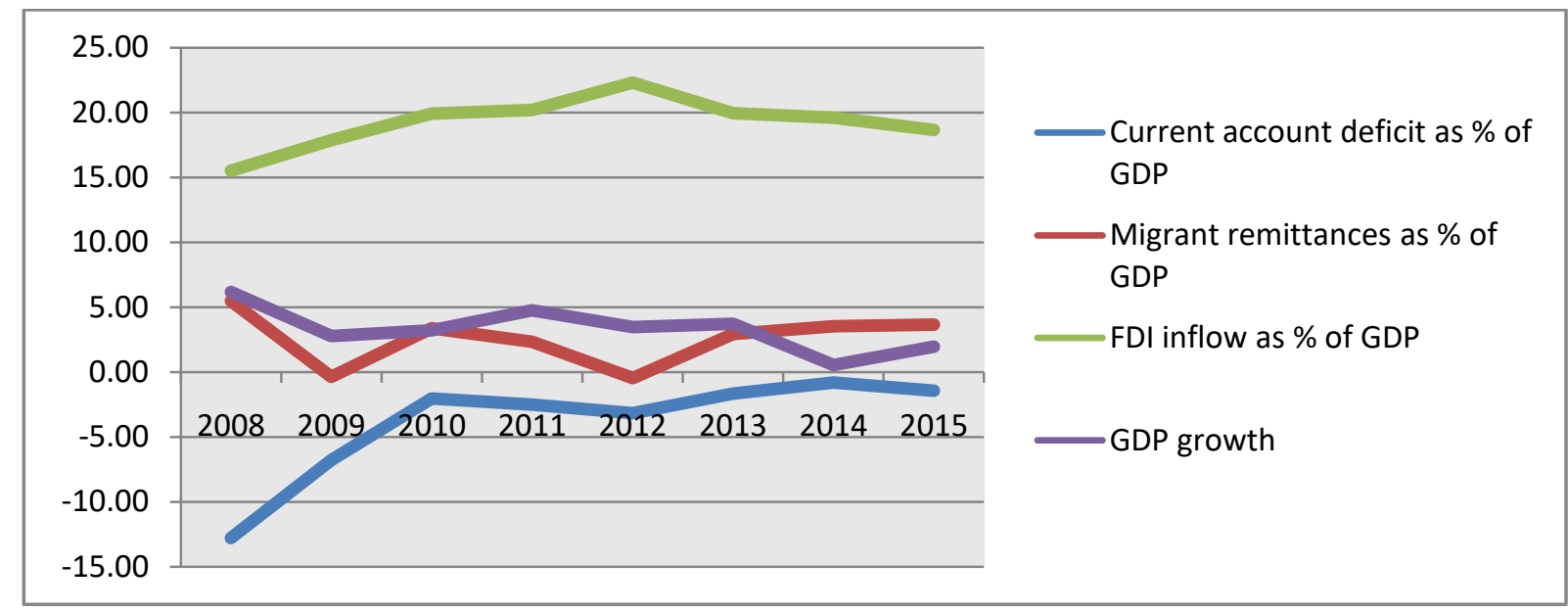

Source: IMF

Montenegro's current account deficit recorded large swings by widening to $-13.25 \%$ in 2015 compared to approximately $-50 \%$ in 2008. The MIP scoreboard indicator suggests that the Montenegrin economy suffers significant external imbalances and the global financial crisis definitely helped the economy heal. In the wake of the crisis, the three year average current account deficit is $-40.2 \%$ of GDP in 2008 which makes Montenegro the highest externally imbalanced EU candidate country. The excessive current account deficit narrowed more than three times over the course of 7 years which put an emphasis on cyclical factors when interpreting the current account balance in Montenegro. Imports significantly exceed the Montenegrin exports in positive economic growth environment in 2013-2015, with low level of migrant remittances and strong FDI inflows (in 2009 FDI inflow doubled compared to 2015). The economy shrank in 2009 and 2012 when economic growth was respectively $-5.7 \%$ and $-2.7 \%$ and the current account deficit automatically narrowed to $-27.9 \%$ of GDP in 2009 and $-18.5 \%$ in 2012 . Hence, the correction of current account balance does not imply that one country gains external competitiveness but also that a country may suffer decreased standard of living and quality of life as a result of the economic slowdown. Another conclusion is that official euro isation does not support foreign trade integration of Montenegro as cyclical factors weigh more on performance of catch-up economies. 
Figure 5: FDI inflows compensated current account deficit in Montenegro

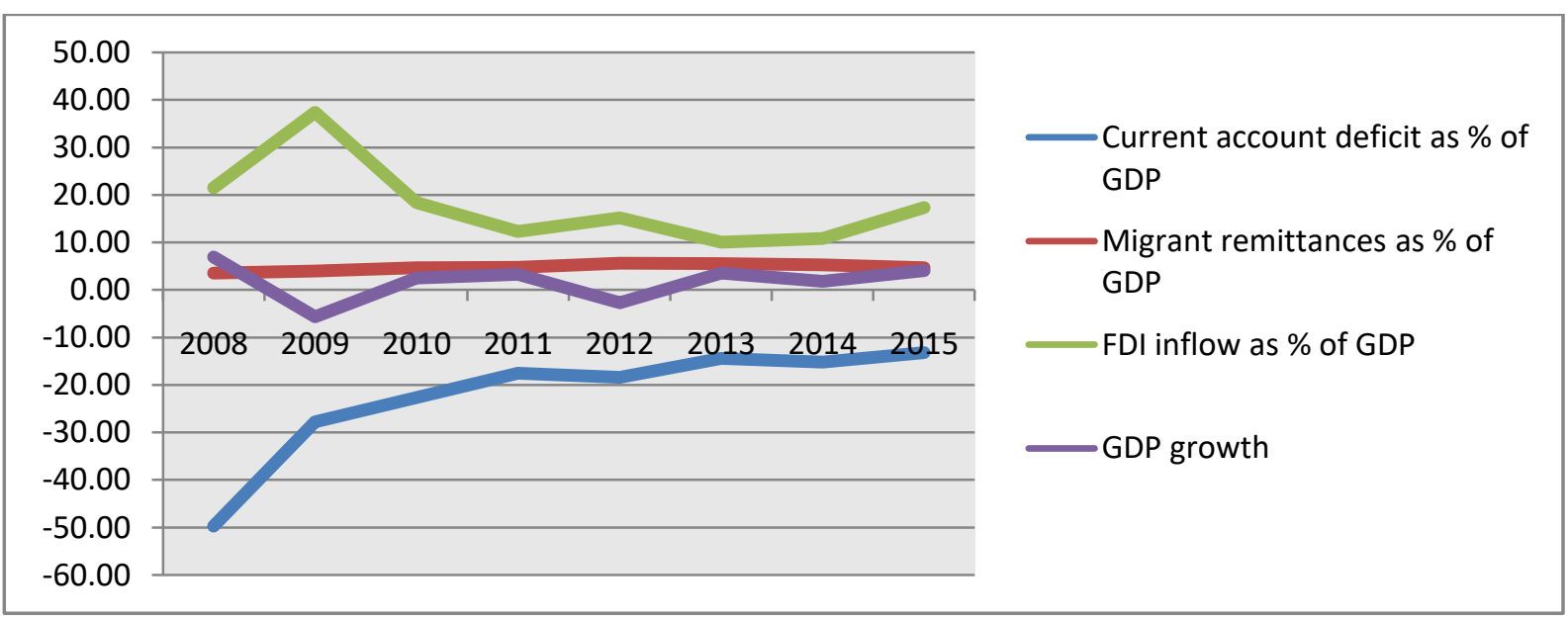

Source: IMF

External imbalances in Serbia follow a similar pattern as the one already observed in relation to Montenegro. The current account deficit fell below $6.3 \%$ of GDP in 2009 when the GDP fell to -3.1 $\%$. Growing exports in a global environment of low energy prices and recession in the euro area and subdued imports in Montenegro due to low economic growth, even negative in 2014 (-1.8\%), reduced the current account deficit to $-4.8 \%$ in 2015. Most of the current account deficit was covered by FDI inflow that peaked to 5 bln USD (11\% of GDP) in 2011, when the negative current account balance amounted to $-18.5 \%$ of GDP and real GDP growth was $1.4 \%$.

Figure 6: FDI inflows and migrant remittances offset current account deficit in Serbia

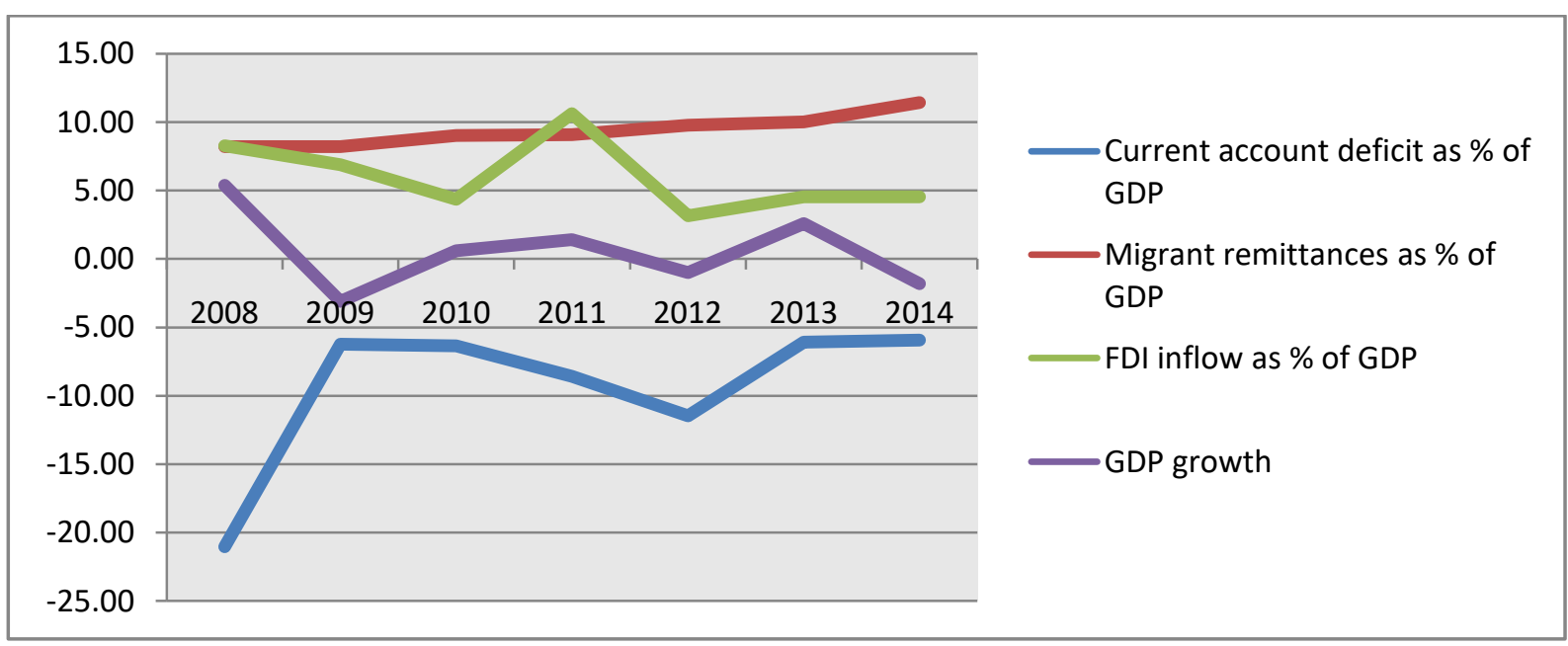

Source: IMF

Migrant remittances also played a significant role in the current account composition and net secondary income stabilized at $9 \%$ of GDP in 2008-2014. In other words, the catching-up pattern of economic growth goes hand in hand with accumulation of external imbalances due to insufficient domestic savings and production potential whose shortage can be compensated by foreign investments and imports, i.e. current account deficits combined with positive capital inflows. In a sense, Bulgaria and Estonia were in a similar position before the crisis. 
Not surprisingly, Turkey's long-lasting high current account deficit has widened since 2008. The slow economic growth since 2011 has helped current account deficit be corrected somewhat but it is still above $-5 \%$ of GDP in 2014. Lower energy prices have favoured the correction of current account deficit in Turkey which is a large energy importer. The negative trade balance in Turkey was not offset with positive net secondary income which proves that migrant remittances are much more significant in less developed economies such as the other Western Balkan countries are.

Figure 7: Economic growth driven current account deficit in Turkey

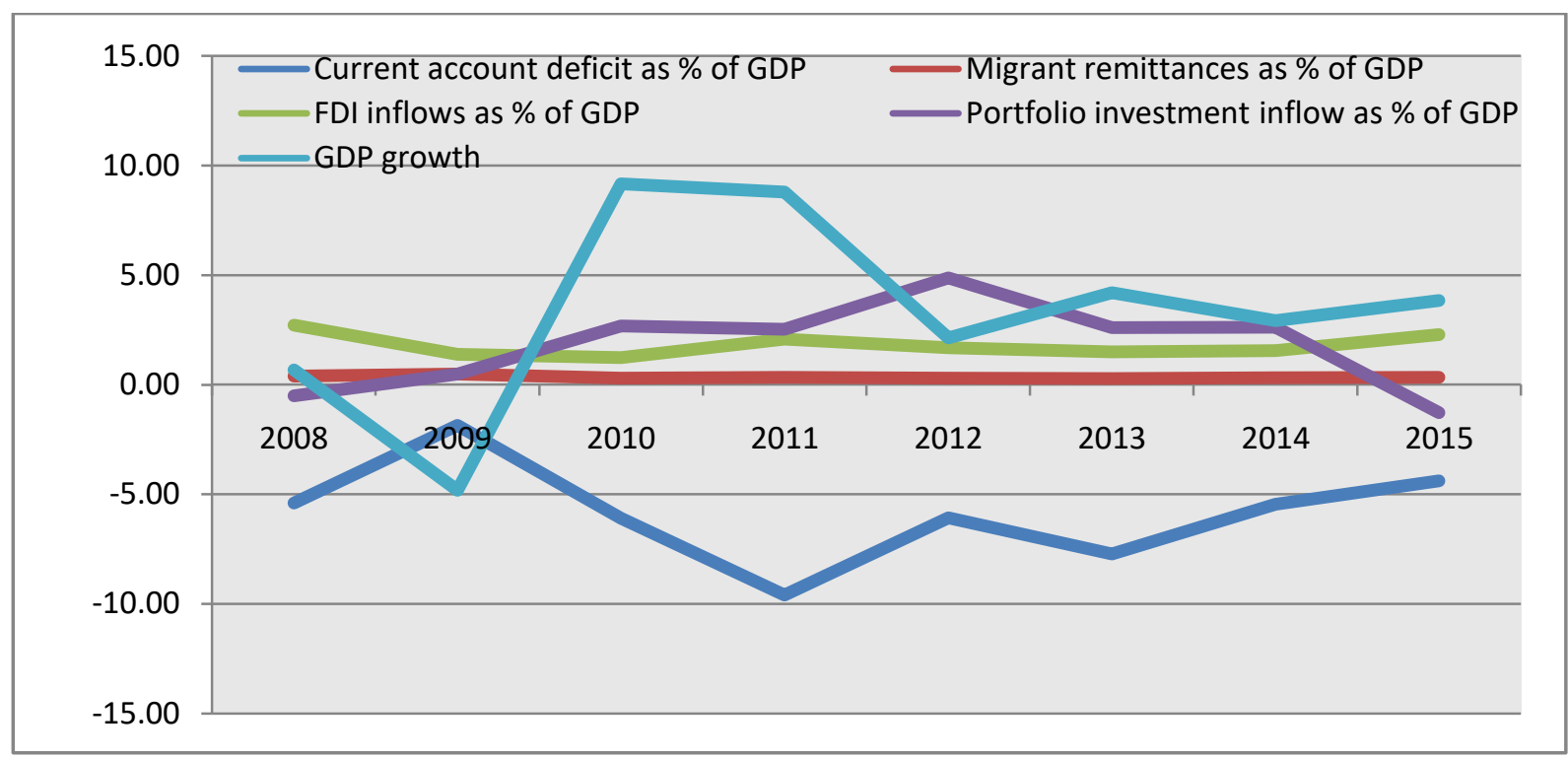

Source: IMF

As regards the financial account composition, portfolio investment inflows (4.86\% of GDP in 2012) are much higher than FDI inflows (1.68 \% of GDP in 2012), which is not the case with other EU candidate countries. Nevertheless, a persistent shortfall of domestic savings drives Turkey's current account deficit which is the common pattern of countries under review. Similarly, the strong economic growth is backed by high raw and energy imports which affects negatively current account balance but is offset with investments by foreign investors, including foreign borrowing by Turkish banks. As long as the country attracts foreign investment ( $5.53 \%$ of GDP FDI and portfolio investments inflow in 2014), the current account deficit ( $-5.46 \%$ of GDP in 2014) is not viewed as a macroeconomic problem since it reflects rapid growth of economy.

The data on current account balances shows that current account divergences between the countries under review narrowed during the crisis owing to the substantial drop in FDI, which is certainly an important factor for a decrease in the current account deficits. It also reflects the change of their economic growth model and reorientation from large FDI inflows to domestic investment possibilities. Another contributing factor to this adjustment is the observed progress in exports. The sharper drop in the private sector demand and the related contraction of import assisted in the current account deficits self-correction. 
Certainly, current account deficits in the region narrowed and yet they are high, whereas it is not clear whether they will return to the pre-crisis extremely high levels. If the FDI resumes in the scope of the pre-crisis volumes the current deficit will most probably widen again. The growth model should be linked to large inflows of FDI and high FDI growth has the potential to accelerate fast catching-up. That is why this imbalance should have established sufficient buffers against such risks.

\section{Net international investment position}

The next MIP scoreboard indicator for assessing external imbalances is the net international investment position (NIIP). Using the data available in the IMF database it could be calculated for all countries except Montenegro. The data clearly shows that net international position deficits of all countries under review widen after 2008.

Figure 8: Net international investment position as a percentage of GDP, period for calculation 20082014*

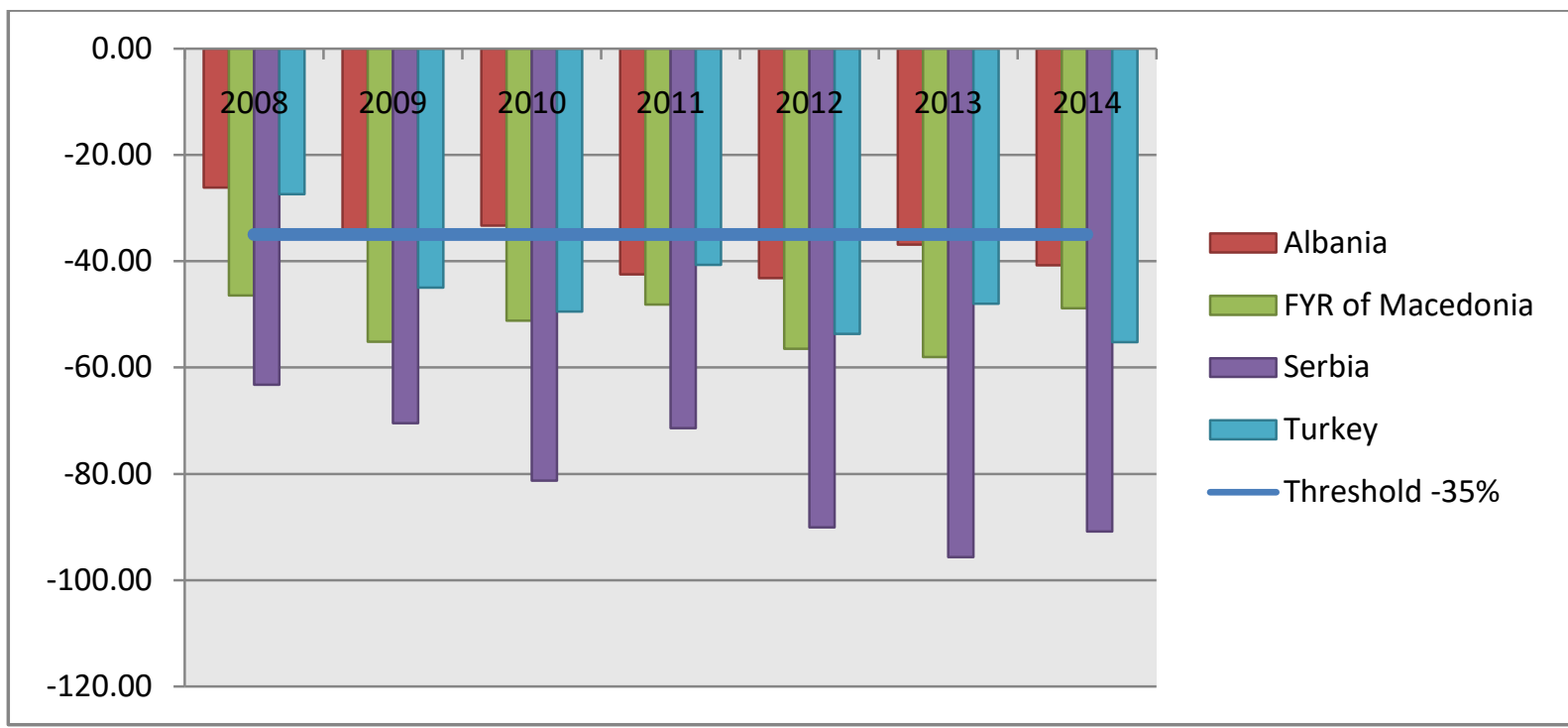

Source: IMF

* No data available for Montenegro.

The calculations of net international investment position as percentage of GDP clearly shows that countries with persistently high current account deficits as EU candidate countries are also debtor nations which reflects the low levels of domestic savings. Catching-up economic development requires strong capital inflows that should compensate low domestic investment capacity and make economic convergence to more developed countries possible. If the investment gap is not narrowed by attracting capital from abroad, a long-lasting sluggish economic growth will prevent catching-up economies from real convergence to their EU peer. This, however, creates a paradox - if a country attracts foreign capital, it makes it vulnerable because high foreign borrowing can pose crisis of confidence and rapid devaluation of national currency if money flow dries up, but if a country catches up, foreign capitals are vital for its economic convergence. Therefore, if we assess a negative net international investment position of a developing country only as a source of risks and vulnerabilities, we also penalize its efforts to become a developed country. 


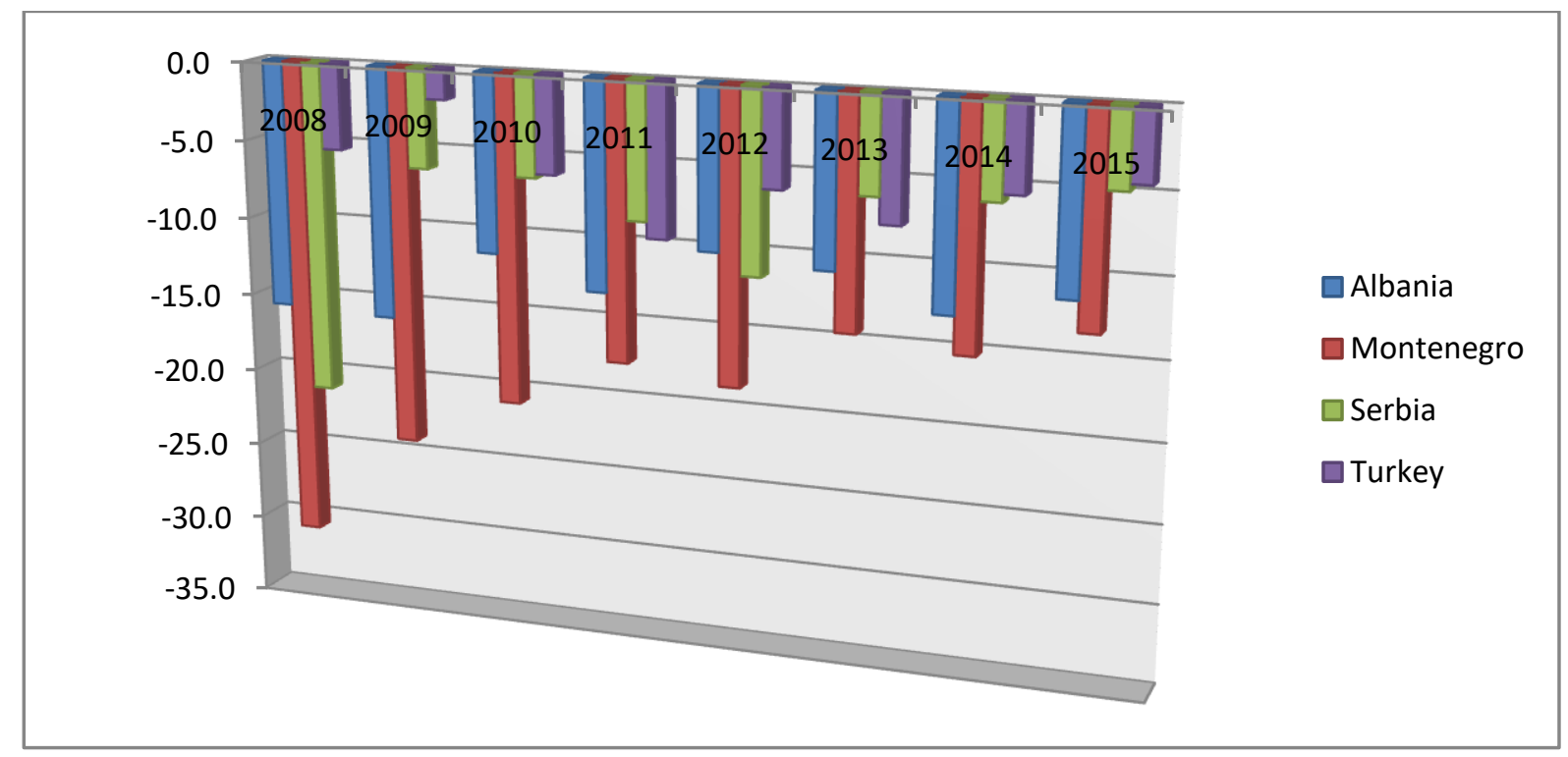

Source: IMF

*Investment gap is the difference between total investment and gross national savings as \% of GDP.

**No data available for FYR of Macedonia.

The data shows that the EU candidate countries suffer shortage of capital to cover their investment which is more severe in Montenegro (-19.3\% of GDP in 2008-2015) and Albania (-12.7\% of GDP in 2008-2015) and less pronounced in Turkey (-5.5\% of GDP for 2008-2015) and Serbia (-8.5 $\%$ in 2008-2015). Meanwhile, the FDI inflow grows and it negatively affects the net international investment positions of the countries under review which, in turn, makes them more successful in filling the investment gap instead of being more vulnerable. Montenegro succeeded in attracting FDI inflow that amounted to $17.82 \%$ of GDP in 2008-2015 and Albania achieved9.05\% of GDP respectively. Not surprisingly, FDI inflows for the observed period in Turkey are only $1.81 \%$ of GDP ( $1.74 \%$ of GDP is portfolio investment inflow) and $6.04 \%$ of GDP in Serbia. The average economic growth in 2008-2015 in the EU candidate countries also proves that they manage to neutralize negative crisis effects, attracting more foreign investment. As a result, negative net international investment position grows: 1.70 \% economic growth in Montenegro in 2008-2015, $3.04 \%$ in Albania, $3.35 \%$ in Turkey, and $0.59 \%$ in Serbia. In addition, decreasing investment gaps in Albania, Serbia and Turkey in recent years are associated with increased net international investment position as a percentage of GDP.

\section{Export market shares}

Another indicator of the MIP scoreboard is the export market share calculated as a five-year percentage change of national export as percent of the world export. The calculations suggest large divergences among the countries and also an extensive dynamic of this indicator. However, in Albania, FYR of Macedonia, Serbia and Turkey export market shares grew till 2012 with a 
negative growth in 2013 and 2014. The export market shares growth in Montenegro is also negative since 2012.

Figure 10: Five year percentage change in export market shares, period for calculation 2003-2014

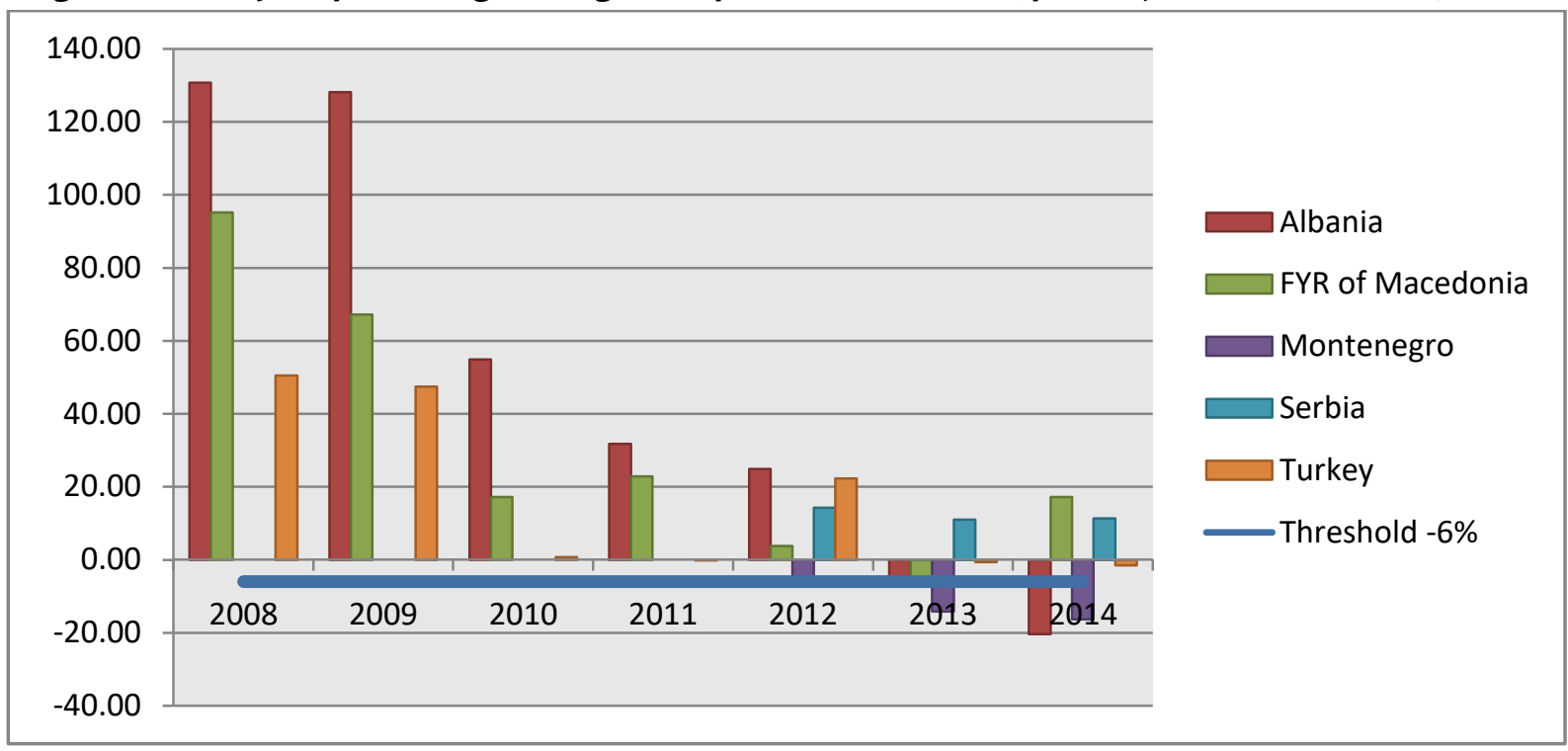

Source: IMF and UNCTAD

Growing export market shares of the EU candidate countries in 2008-2011 was associated with improved productivity and depreciating real exchange rates in a situation of a weaker global demand. The export-led recovery is also the pattern of economic development of EU candidate countries after 2008. The recorded gains in export market shares are driven not only by the increase of the countries' exports volume but also by the growth of total world exports in goods and services which increased by almost $20 \%$ in 2014 compared to its value in 2008. Moreover, the main trading partner of most EU candidate countries, especially the Western Balkan countries, is the EU whose imports have grown by $16.3 \%$ in 2008-2015. The low production costs in EU candidate countries also played a role in strengthening their price competitiveness. Further, most of the export corporations in EU candidate countries are owned by foreign investors. This constitutes an indirect channel of FDI inflows that affects GDP and improves export performance.

The exports in Albania remained highly concentrated in some manufacturing sectors of the economy as mineral products, clothing and textiles and metals with stable demand during the global financial crisis which was a factor contributing to the growing export market share of the country. The improvement in the trade balance of FYR of Macedonia is mainly due to the export of products with higher value added as machinery, automotive components and transport equipment. This diversification of export notwithstanding, it still remains concentrated in metal and steel, clothing and food. The loss in export market shares in Montenegro is predominantly a result of the export structure of the country that consists of low added value products. In addition, a few Montenegrin companies trade internationally which also negatively affects the export potential of the country. Strong export growth in Serbia in 2008-2015 is driven by food, clothes and non-ferrous metals. Food and clothes prices continued an upward trend during the crisis and this price effect contributed significantly to the high export growth in Serbia. The Turkish exports benefited from a more competitive exchange rate and growing exchange market 
shares. The major exports of Turkey are clothing, automotive and iron where the price effect on export volumes is relevant as in the case of Serbia. It is worth noting that high export concentration of EU candidate countries in certain economic sectors and the EU as a main trade partner may expose their economies to industry-specific shocks and negative geographical orientation impact on their export and consequently to their GDP growth and economic convergence.

\section{Assessing internal imbalances in EU candidate countries}

We assess the sustainability of internal position of the EU candidate countries only on the basis of their general government indebtedness and unemployment and activity rates. The indicator for general government debt offers a broader picture of country indebtedness as a high public debt increases the overall macroeconomic vulnerability of a country and weakens its room for maneuvering when dealing with crisis. In the post-crisis times this indicator also transforms into leading indicator of macro-economic development at all. The indicators on labour market are intended to monitor a potential mismatch of resources and general lack of adjustment capacity in economy.

\section{General government debt}

Since 2011 all EU candidate countries are below the threshold of the indicator which implies low perceived sovereign and financial sector risks and also high state creditworthiness. Moreover, the general government debt levels are significantly below the indebtedness levels in most EU Member States.

One of the reasons for this is that those countries were not experiencing banking crisis and no public money was used for the rescue of banks. On top of that, FYR of Macedonia, Montenegro and Turkey had not borrowed from the IMF and other sources during the global crisis. After 2012 Albanian public debt increased to $71.9 \%$ of GDP in 2015 and domestic banks hold a large part of it. This causes concerns about financial stability in Albania and fosters fiscal consolidation which may be a drag on economic growth. Serbia's high public indebtedness also creates financial risks and within only three years after 2012 the general public debt as a percent of GDP increased by 19.1 p.p. Meanwhile, the average GDP growth in Serbia in 2012-2015 was close to zero which clearly implies that high levels of public debt did not stimulate economic growth in the country during the period under review. On the other hand, general government debt levels in FYR of Macedonia and Turkey are comparatively moderate, even decreasing in the latter country (39.14\% of GDP in 2011 and $32.61 \%$ of GDP in 2015 in Turkey). The average GDP growth in 2012-2015 in FYR of Macedonia is $2.42 \%$ and respectively $3.27 \%$ in Turkey. 
Figure 11: General government debt as a percentage of GDP, Period for calculation 2008-2015

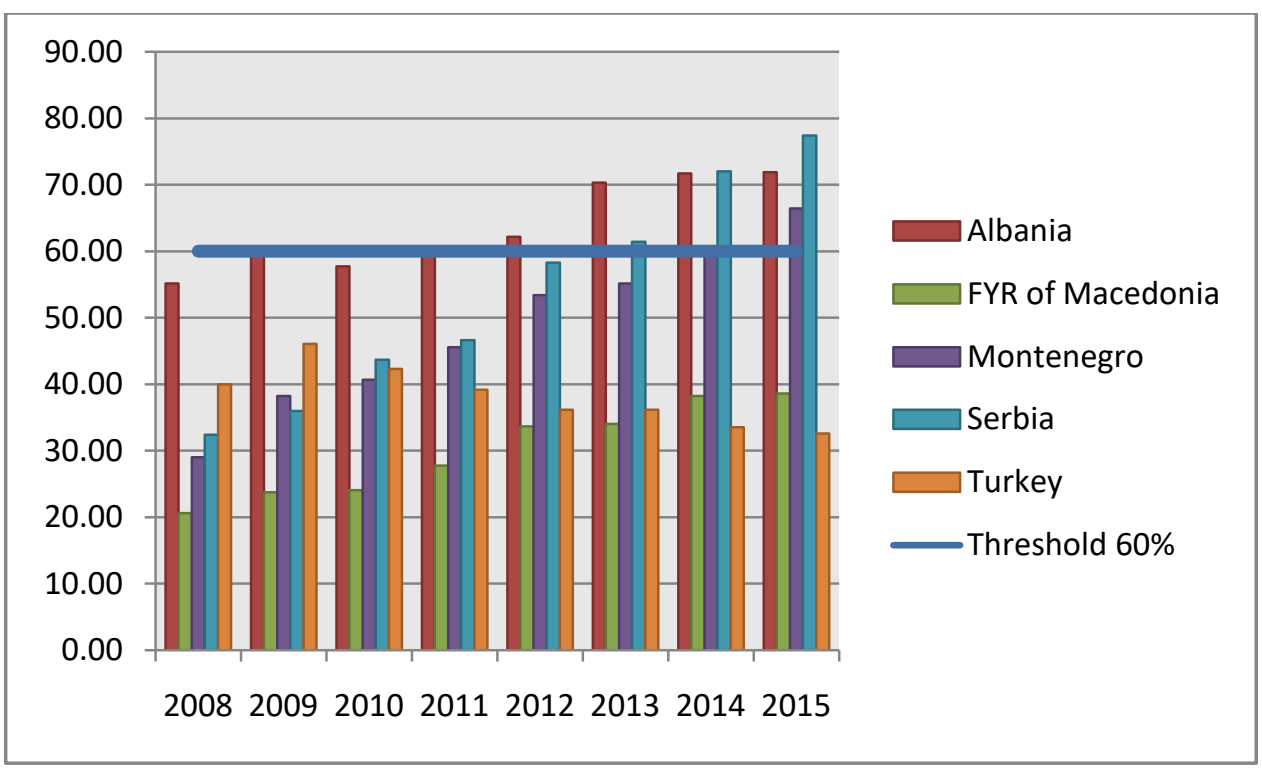

Source: IMF

The issue of whether high public debt is harmful for economy is still a cause for controversy, but these figures show a negative correlation between public debt levels and growth capacity which justifies fiscal austerity in Albania and Serbia and gives fiscal space for a more expansionary macroeconomic policy in FYR of Macedonia and Turkey with average budget deficits below $-3 \%$ of GDP in 2008-2015.

Figure 12: Budget deficits as \% of GDP

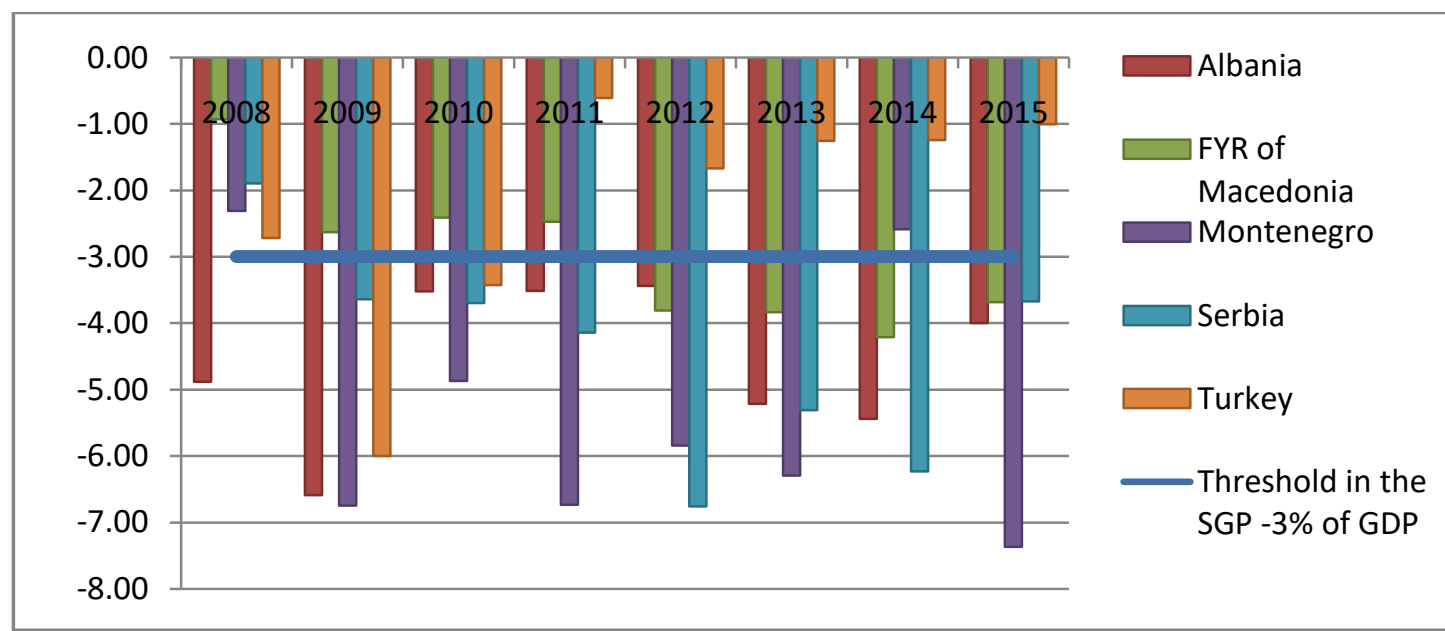

Source: IMF

Compared to the external imbalances indicators where all EU candidate countries follow an almost identical pattern of external economic development, the public debt indicator shows that they are not a homogenous group with a view to their indebtedness. As regards Montenegro, the differences are also clear. The public debt in Montenegro was growing in the whole period under review and in 2015 it was $66.4 \%$ of GDP. In fact, total public debt doubled since 2008 but only for 
three years the economic growth accelerated to $4.1 \%$ in 2015 compared to $-2.72 \%$ in 2012 . The budget deficit for the period 2008-2015 amounted to $-5.3 \%$ of GDP in Montenegro and it classifies the country in one group with Albania and Serbia with average budget deficits above $-4.5 \%$ of GDP, at the same time contrasting them to Turkey and to an extent to FYR of Macedonia, especially before 2012, in that they try to keep their budget deficits low whilst being fiscally prudent.

\section{Unemployment rate and Activity rate}

For the most part of the period under review, the only EU candidate country that is below the threshold of $10 \%$ three year average unemployment rate is Turkey. All other Western Balkan countries run high and persistent levels of unemployment, exceeding the threshold for all the periods under review. By all means the countries reach record high unemployment rates - the unemployment in FYR of Macedonia peaked at around 30\%, in Serbia since 2011 it was more than 20\%, while in Montenegro it was close to 19\% and in Albania below $15 \%$ until 2014.

\section{Figure 13: Three year backward moving average of unemployment rate, period for calculation}

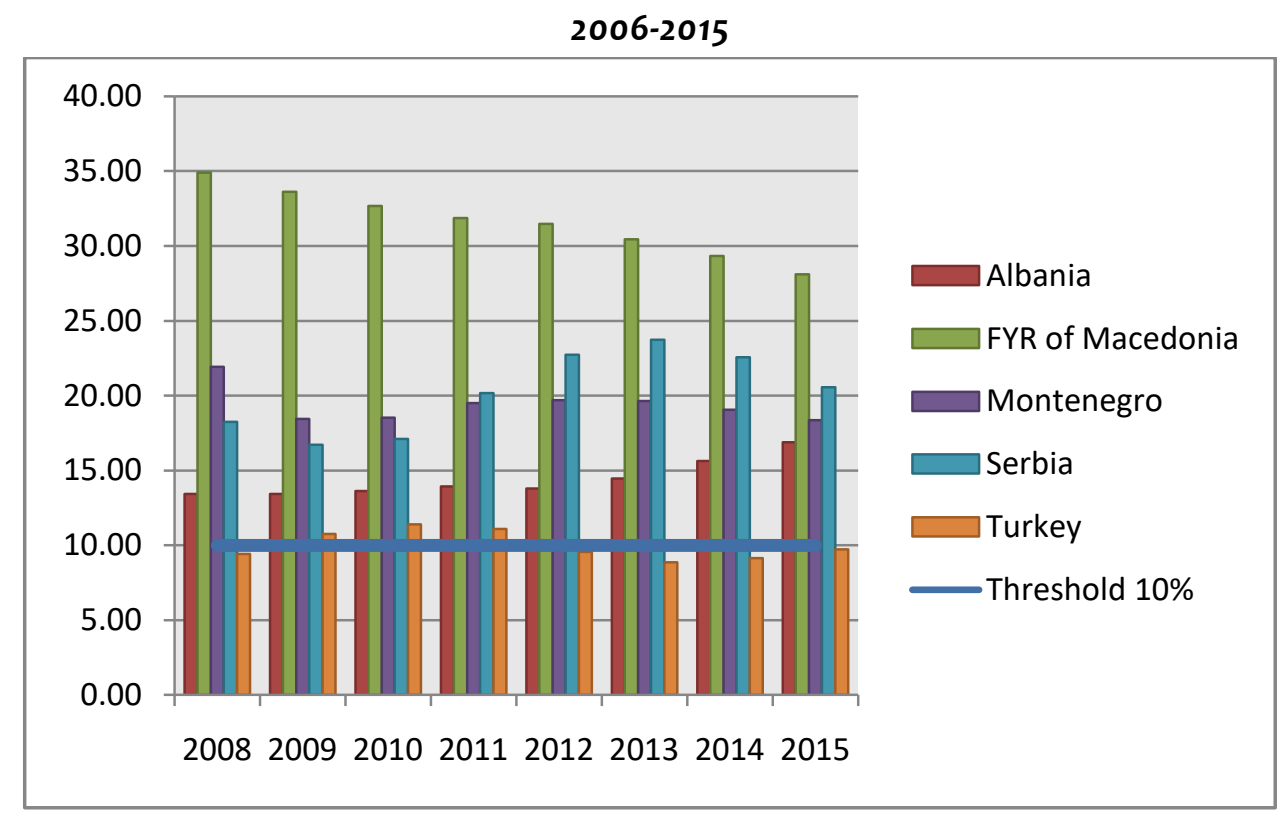

Source: IMF and Statistical Office of Montenegro

The unemployment rates in Western Balkan countries began to moderately slow down as late as 2015 which clearly shows delayed economic recovery and an ineffective social and production structure. The data suggest that the high unemployment is not only on the back of the recent crisis but results from structural changes in employment as the less qualified find it more difficult to get a job. The crisis though added to unemployment partly due to the reduction of some highgrowth sectors such as construction and related sectors. On the other hand, low unemployment may put upward pressure on wages over labour productivity and negatively affect negatively the competitiveness of the economy. 
Figure 14: Activity rate (15-64 years), period for calculation 2008-2015

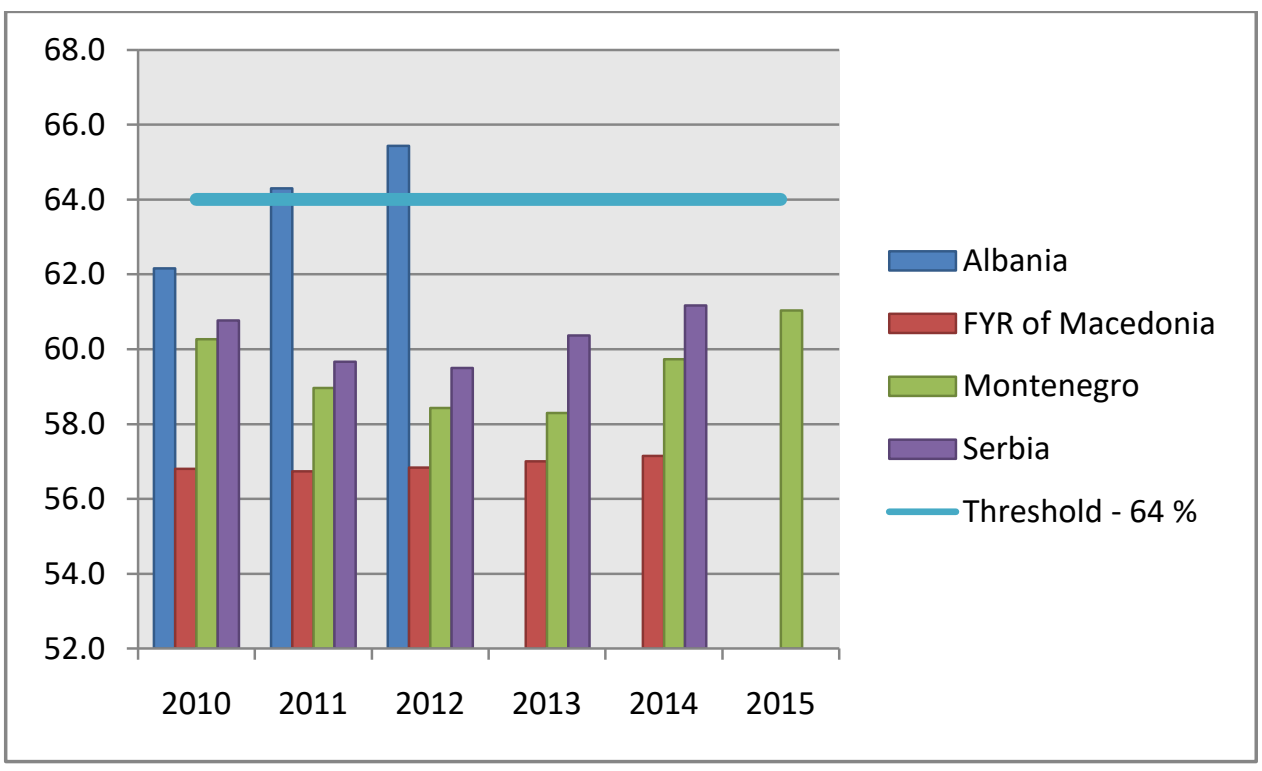

Source: National statistical offices of Albania, FYR of Macedonia, Montenegro and Serbia

Against the backdrop of persistently high unemployment rates in Western Balkan countries, activity rate is also below the threshold of $64 \%$ in these countries although percent point change of the indicator over 3 years is persistently above $-0.2 \%$.

Figure 15: Percent point change of activity rate over 3 years period

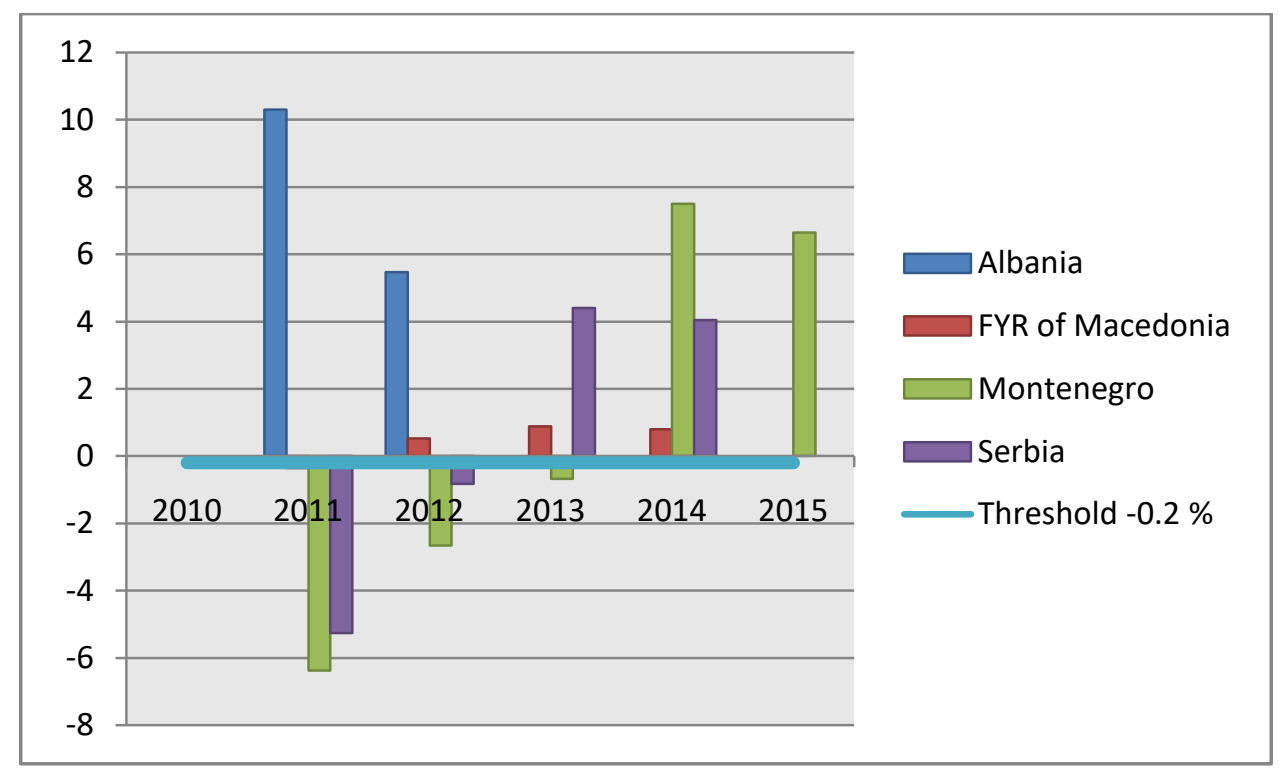

\section{Source: National statistical offices of Albania, FYR of Macedonia, Montenegro and Serbia}

The predominance of long-term and youth unemployment in them resulted in huge labour market imbalances and structural obstacles with a significant effect on domestic demand. The weak labour market conditions exert contracting pressure on wages and private consumption which negatively affect the economic growth and make foreign capital inflows more than essential for national economic development. Subdued domestic demand due to high unemployment and 
falling wages weighs heavily on recovery efforts and makes countries accumulate large budget deficits, high levels of public debt and attracts foreign capitals. In terms of the social conditions, such a macroeconomic environment motivates people to emigrate and high migration rates, especially of highly-skilled workers, are also typical for the Western Balkan economies. In other words, migrant remittances not only help narrow current account deficits in these countries but also compensate low activity rates and affect national economic resilience in tackling unfavourable social conditions.

Unfortunately, there are no comprehensive and comparable data so as to calculate the unit labour costs that are important for the assessment of the economic developments and the related imbalances.

\section{Conclusions}

The calculation of the MIP scoreboard indicators for the EU candidate countries reveals a lot of similarities in the imbalances pattern between the countries under review. The analysis of the imbalances suggests that they are not only linked to the crisis but also to the restructuring of the economy and the caching-up process. The relative resilience of the crisis proves the flexibility and capabilities for adjustment of those economies.

Figure 16: MIP scoreboard for EU candidate countries in 2014*

\begin{tabular}{|l|c|c|c|c|c|c|}
\hline \multirow{1}{*}{ Country } & \multicolumn{3}{|c|}{ External imbalances and } & \multicolumn{3}{c|}{ Internal imbalances } \\
\cline { 2 - 7 } & $\begin{array}{c}\text { Current } \\
\text { account } \\
\text { balance }\end{array}$ & $\begin{array}{c}\text { Net } \\
\text { international } \\
\text { investment } \\
\text { position }\end{array}$ & $\begin{array}{c}\text { Export } \\
\text { market } \\
\text { share }\end{array}$ & $\begin{array}{c}\text { General } \\
\text { government } \\
\text { debt }\end{array}$ & $\begin{array}{c}\text { Unemployment } \\
\text { rate }\end{array}$ & $\begin{array}{c}\text { Activity } \\
\text { rate }\end{array}$ \\
\hline Thresholds & $\begin{array}{c}+6 \% /-4 \% \\
\text { of GDP }\end{array}$ & $-35 \%$ of GDP & $-6 \%$ & $60 \%$ of GDP & $10 \%$ & $-0.2 \%$ \\
\hline Albania of & -11.3 & -40.8 & -20.4 & 71.7 & 15.6 & \\
\hline $\begin{array}{l}\text { FYR of } \\
\text { Macedonia }\end{array}$ & -1.9 & -48.8 & 17.2 & 38.3 & 29.3 & 0.9 \\
\hline Montenegro & -16.1 & & -16.3 & 59.9 & 19.1 & 7.5 \\
\hline Serbia & -7.8 & -90.9 & 11.4 & 72.0 & 22.6 & 4.0 \\
\hline Turkey & -6.4 & -55.2 & -1.5 & 33.5 & 9.1 & \\
\hline
\end{tabular}

Source: Own calculations

*The red figures correspond to the values of the indicator breaching the threshold.

The external imbalances that countries experience reflects the catching-up profiles of their economies that exhibit common macroeconomic developments related to the nature of the process itself. The catching-up pattern of economic growth in the countries under review goes hand in hand with accumulation of external imbalances due to insufficient domestic savings and production potential whose shortage can be compensated by foreign investments and imports. With regard to economic convergence this creates a paradox - if a country attracts foreign capital, it makes it vulnerable because high foreign borrowing can pose crisis of confidence and rapid devaluation of national currency if money flows dry up, but if a country is poor, foreign 
capitals are vital for its economic convergence. In addition, FDI inflow helps catching-up economies fill their investment gaps - a process which, if assessed negatively as a source of risks and vulnerabilities with regard to the FDI-driven growth model, also penalizes the country's efforts to be a developed country. The export-led recovery where most of the export corporations in EU candidate countries are owned by foreign investors and the average economic growth in 2008-2015 in the EU candidate countries also proves that they manage to neutralize negative crisis effects by attracting more foreign investment. The paradox is that the values of the indicators suggest that the recent turmoil helped resolve some of the imbalances.

As regards internal imbalances, Turkish economy has less in common with Western Balkans countries. The public debt indicator shows that they are not a homogenous group as far as their indebtedness goes. Albania, Montenegro and Serbia can be classified in one group with high public debt and budget deficits, while Turkey and to a certain degree FYR of Macedonia, especially before 2012, try to keep their budget deficits low whilst being fiscally prudent. Subdued domestic demand in the Western Balkans countries due to high unemployment and falling wages weighs heavily on recovery efforts and makes countries accumulate large budget deficits, high levels of public debt and attraction of foreign capitals. The substantial migrant remittances in these countries not only help narrow their current account deficits but also compensate low activity rates and affect national economic resilience with regard to tackling unfavourable social conditions, which is definitely not the case for Turkey.

Regarding the applicability of the MIP scoreboard principles and calculation of indicators, it is worth mentioning that insufficient statistical data for the calculation of the MIP scoreboard indicators is not only a challenge when assessing their convergence in the terms of EC concepts but also in legal terms. This means that credible statistics is a precondition for joining the EU because the readiness and economic convergence should be assessed according to the imbalances the countries experience which should be quantifiable in a comparable manner.

The issue that the countries under review still experience significant external and internal imbalances should not be neglected and if they join the EU while not being on a consistent path to correct them, it is possible to observe again the situation when Croatia joined the EU in 2013 and was identified as a country with excessive imbalances. Insufficient economic convergence, even if often politically neglected, creates long-lasting negative effects of a different nature. Such situations can be called "Croatia syndrome" and they should be prevented. The most important goal of economic policy is to resume economic growth and sustain public finances as well. It is of the utmost importance for the caching-up economies to grow fast. The creation of imbalances could be then compensated by a prudent fiscal policy and structural reforms, therefore creating buffers that will protect the economy from the risks built on the back of the imbalances.

\section{References}

1. Bobeva, D. (2013), The new EU Macroeconomic Imbalances Procedure and its Relevance for the Candidate Countries, Journal of Central Banking Theory and Practice 2(1), Central Bank of Montenegro

2. European Central Bank (2012\&2014), Convergence Report

3. European Commission (2011), Scoreboard for the surveillance of macroeconomic imbalances: envisaged initial design /Commission Staff Working Document/ 
4. European Commission (2015),Adding employment indicators to the scoreboard of the Macroeconomic imbalance procedure to better capture employment and social developments/Commission Staff Working Document/

5. European Commission (2012-2015), Progress Reports for Albania, FYR of Macedonia, Montenegro, Serbia and Turkey

6. European Parliament (2014), Report on the European Semester for economic policy coordination: implementation of 2014 priorities

7. Fry, M. J. (1995), Foreign Direct Investment, Other Capital Flows and Current Account: What Causes What?, World Bank

8. International Monetary Fund, World Economic Outlook Databases and Balance of Payments Statistics

9. Ministry of Finance of the Republic of Macedonia, Pre-accession Economic Programme 2013-2015

10. Regulation (EU) No 1176/2011 of 16 November 2011 on the prevention and correction of macroeconomic imbalances.

\section{About the Authorship:}

Dr. Dimitar Zlatinov has extensive professional experience at the Bulgarian National Bank. Currently, Mr. Zlatinov has conducted lectures and seminars in Macroeconomics and Macroeconomic Analysis, Microeconomics, Economic policy and International Economics in two Bulgarian universities. He has 25 publications in the area of economic growth theory, fiscal and monetary policies and their coordination, development of macroeconomic modeling and labor market issues. Dimitar Zlatinov also took part in 5 research projects aimed at analysing foreign trade relations, investment activity, short-term and long-term factors stimulating economic growth in Bulgaria and professional and educational structure of employed people and the labour force. In 2014 Mr. Zlatinov participated in the Fifth Lindau Meeting on Economic Sciences in Germany and has professional specializations in Austria, Luxembourg and the Czech Republic. 